\title{
RISK FACTORS STUDY OF ACUTE INFECTION RESPIRATORY SYNDROME IN DISTRICT OF BANJARNEGARA
}

\author{
Eny Sofiyatun, Barnidan Vita Rahayuningsih \\ Environmental Health Study Program of Banjarnegara Polytechnic, Banjarnegara \\ email: enysofi@polibara.ac.id
}

\begin{abstract}
Background: Infection of Respiratory Syndrome is one of the cause main illness on toddler in developing country. The aim of this research was to know risk factors which influenced on Respiratory Syndrome infection, it cases in Aribaya Village, Sub-District of Pagentan, District of Banjarnegara in 2012. The risk factors included age, gender, conditions of house (included ventilations, floor, lighting, temperature and humidity), mother's knowledge, the existence of smokers of family members, education level and occupation of mother.

Method: This research used observational method with cross sectional design. 64 respondenst were participated in this research. Respondent was a person who have children under 14 years old. Random sampling technique was used to obtain data. Univariat and bivariat analyze with chi square test using SPSS 17 program was used.

Result: This research revealed that there was relationship between the conditions of house ventilations $(p=0.001)$, the kinds of floor $(p=0.004)$, lighting $(p=0.001)$, mother's knowledge $(p=0.001)$. Others factors that do not have any correlations are ages $(p=0.396)$, gender $(p=$ $0.080 \mathrm{~A})$, the existence of smokers of family members $(p=0.355)$, education level of mother $(p=.0134)$ and occupational of mother $(p=0.284)$.

Conclusion: The recommendations were reconstructions the conditions of house according to health houses requirements. It was needed closed counseling to community from Health Center Department and local government.
\end{abstract}

Keywords: risk factor, respiratory syndrome, Banjarnegara, toddler and mother health

\section{Introduction}

Acute infection respiratory syndrome is one of health problem in developing country, including Indonesia. It causing by the highest of cases value and death value, especially Pneumonia on baby and toddler cases. Acute infection respiratory syndrome cases in Indonesia are 10-20\%. ${ }^{1}$ The report of RISKESDAS 2007 also reveal that the highest respiratory syndrome prevalence on toddler cases (>35\%) in family wich low of salary and education. Prevalention of respiratory syndrome in Central Java province is $29.08 \%{ }^{2}$

There are many factors that causing respiratory syndrome, either direct and nondirect factors. The Ministry of Health (2002) explain that risk factors of respiratory syndrome on baby and toddler are social-economics factors (include: salary, the conditions of houses, education of toddler's parents mainly mother), environmental factors (likes air quality and density of houses), nutritions status, not-completed of imunzitations, and BBLR cases. ${ }^{3}$

The environmental factors that influenced on respiratory syndrome cases process are the quality of houses, they are the kind of roofs, floors and walls, the density of family member and the kind of household fuel. Other researchs shows that the risk factors are toddler's father are smoker, the low of awereness to open window on the day that influenced the humidity of houses, and the lack of breastmilk that influenced the imunnity of babies. ${ }^{4-7}$ 
Respiratory syndrome cases in Aribaya Village are the major health problem. Respiratory syndrome cases in 2011 are 139 cases that consists of $0-1$ years old are 7 cases, 1-4 years old are 31 cases and upper 5 years old are 101 cases. It needs a research to study about risk factors that influenced respiratory syndrome cases in Aribaya Village.

\section{Research Method}

This research was cross sectional study. The subjects were interviewed by quistionare. This research was held in June, 2012 in Aribaya Village, Sub-district of Pagentan, District of Banjarnegara.

The population were all of the Aribaya community/family that have childrens under 14 years old. The total populations are 509. The sample size of this research was 64 according to Murti $(2006)^{8}$ :

The equations:

$$
\begin{aligned}
& n=\frac{N \cdot Z^{2} \cdot 1-\alpha / 2 \cdot p \cdot q}{d^{2}(N-1)+Z^{2}-\frac{M}{2} \cdot p \cdot q} \\
& \mathrm{n}=\frac{509 \cdot(1,96)^{2} \cdot(0,95) \cdot(0,05)}{(0,05)^{2}(509-1)+(1,96)^{2}(0,95) \cdot(0,05)} \\
& n=\frac{509 \cdot(3,8416) \cdot(0,0475)}{(0,0025)(508)+(3,8416)(0,0475)} \\
& \mathrm{n}=\frac{92.900284}{1.27+0,182476} \\
& \mathrm{n}=\frac{92.880284}{1.452476} \\
& n=63,946 \\
& \mathrm{n}=64 \text { orang }
\end{aligned}
$$

$\mathrm{n}=$ Amount of samples

$\mathrm{N}=$ Amount of populations

$\mathrm{p}=$ The estimations of proportions (prevalence), it a dependen variable in a populations (95\%)

$q=1-p$

$\mathrm{Z} 1-\alpha / 2=z$ statistic $(z=1.96$ for $\alpha=0.05)$

$\mathrm{d}=$ absolute precition delta or margin of error that wanted on two sites proportions $( \pm 5 \%)$.

Observations was done by direct observations using quistionare for the samples and checklist for house conditions. The measurements consists of temperatures and humidity of houses using thermometer and sling hygrometer. Data analyzed by univariate and bivariate analyzed using SPSS program. Chi square test have used to test the related of risk factors in this research to respiratory syndrome cases. 


\section{Results and Analysis}

a. General Descriptive of Respiratory Syndrome Cases in Aribaya Village in 2012

Tabel 1. The age of Respiratory Syndrome Cases in Aribaya Village in 2012

\begin{tabular}{ccccccc}
\hline Age & \multicolumn{2}{c}{ Cases } & \multicolumn{2}{c}{ Non-Cases } & \multicolumn{2}{c}{ Total } \\
\cline { 2 - 7 } (years old) & $\mathbf{n}$ & $\%$ & $\mathbf{n}$ & $\%$ & $\mathbf{n}$ & $\%$ \\
\hline $0-1$ & 9 & 28.12 & 4 & 12.50 & 13 & 20.31 \\
$1-4$ & 14 & 43.76 & 13 & 40.63 & 27 & 42.19 \\
$>5$ & 9 & 28.12 & 15 & 46.87 & 24 & 37.50 \\
Total & $\mathbf{3 2}$ & $\mathbf{1 0 0}$ & $\mathbf{3 2}$ & $\mathbf{1 0 0}$ & $\mathbf{6 4}$ & $\mathbf{1 0 0}$ \\
\hline
\end{tabular}

The result of Chi square test showed there is a not-correlation between age with respiratory syndrome cases by $P$ value 0.396 . It according to Said et al cit. Ayu (2009) that infection of respiratory diseases are in highest cases on baby (6-12 month). ${ }^{9}$ It causing the immunity systems not yet perfect and the respiratory system still narrow. The respiratory syndrome cases on baby under 1 years old will be more acute than upper 1 years old.

b. The Genderof Respiratory of Syndrome Cases in Aribaya Village in 2012

Tabel 2. The Gender of Respiratory Syndrome Cases in Aribaya Village in 2012

\begin{tabular}{ccccccc}
\hline \multirow{2}{*}{ Gender } & \multicolumn{2}{c}{ Cases } & \multicolumn{2}{c}{ Non-Cases } & \multicolumn{2}{c}{ Total } \\
\cline { 2 - 7 } & $\mathbf{n}$ & $\%$ & $\mathbf{n}$ & $\%$ & $\mathbf{n}$ & $\%$ \\
\hline Male & 20 & 62.50 & 13 & 40.63 & 33 & 51.56 \\
Female & 12 & 37.50 & 19 & 59.37 & 31 & 48.44 \\
Total & $\mathbf{3 2}$ & $\mathbf{1 0 0}$ & $\mathbf{3 2}$ & $\mathbf{1 0 0}$ & $\mathbf{6 4}$ & $\mathbf{1 0 0}$ \\
\hline
\end{tabular}

The result of Chi square test showed there is a not-correlation between gender with respiratory syndrome cases by $P$ value 0.080 . Ayu (2009) explain that gender is a internal factor that decided nutritions needs of a person. ${ }^{9}$ Malnutritions cases prevalence of male is higher than female. It is not-according to result of chi square test on this research although in the field the male cases is higher than female. It needs nutritions status research in the future.

c. The Conditions of Ventilations of Respiratory Syndrome Cases in Aribaya Village in 2012

Tabel 3. The Conditions of Ventilations on Respiratory Syndrome Cases in Aribaya Village in 2012

\begin{tabular}{ccccccc}
\hline \multirow{2}{*}{ Ventilation } & \multicolumn{2}{c}{ Cases } & \multicolumn{2}{c}{ Non-Cases } & \multicolumn{2}{c}{ Total } \\
\cline { 2 - 7 } & $\mathbf{N}$ & $\mathbf{0}$ & $\mathbf{n}$ & $\%$ & $\mathbf{n}$ & $\%$ \\
\hline $10 \%$ of the floor & 3 & 9.37 & 17 & 53.12 & 20 & 31.25 \\
$<10 \%$ of the floor & 29 & 90.63 & 15 & 46.88 & 44 & 68.75 \\
Total & $\mathbf{3 2}$ & $\mathbf{1 0 0}$ & $\mathbf{3 2}$ & $\mathbf{1 0 0}$ & $\mathbf{6 4}$ & $\mathbf{1 0 0}$ \\
\hline
\end{tabular}

The result of Chi square test showed there is a correlation between the conditions of floor with respiratory syndrome cases by $P$ value 0.001 . According to Permenkes RI No.829/1999 about Health Houses Requirements explain that physical, chemical and biological conditions of a house is very support the people to reach a good quality of health. Fresh air is need to exchange the air that was used by ventilation. The ventilation is a permanents ventilations that makes air comfortable and contribute to makes temperatures and humidity of houses in a 
good quality. Cross ventilations is recommended to makes a good air flows. This research shows that almost of sample (29 houses) are not have ventilations that fullfil requirements.

d. The Conditions of Floors of Respiratory Syndrome Cases in Aribaya Village in 2012

Tabel 4. The Conditions of Floors on Respiratory Syndrome Cases in Aribaya Village in 2012

\begin{tabular}{ccccccc}
\hline The kind of Floor & \multicolumn{2}{c}{ Cases } & \multicolumn{2}{c}{ Non-Cases } & \multicolumn{2}{c}{ Total } \\
\cline { 2 - 7 } & $\mathbf{n}$ & $\%$ & $\mathbf{n}$ & $\%$ & $\mathbf{n}$ & $\%$ \\
\hline Good & 21 & 65.63 & 31 & 96.88 & 52 & 81.25 \\
Not-Good & 11 & 34.37 & 1 & 3.12 & 24 & 18.75 \\
Total & $\mathbf{3 2}$ & $\mathbf{1 0 0}$ & $\mathbf{3 2}$ & $\mathbf{1 0 0}$ & $\mathbf{6 4}$ & $\mathbf{1 0 0}$ \\
\hline
\end{tabular}

The result of Chi square test showed there is a correlation between the conditions of floor with respiratory syndrome cases by $P$ value is $0.04<\alpha(0.05)$. Almost of respondens have a conditions of floor mades from "plester" and soil that causing dust on dry season and high humidity on wet season. Dust is a good media transmitions of microorganism which one of them can causing respiratory syndrome. A good floor are not have high humidity, water resistance, easy for cleaning and when it dry do nut dust resulting. ${ }^{3}$

e. The Conditions of Houses Lighting of Respiratory Syndrome Cases in Aribaya Village in 2012

Tabel 5. The Conditions of Houses Lightingof Respiratory Syndrome Cases in Aribaya Village in 2012

\begin{tabular}{ccccccc}
\hline \multirow{2}{*}{ Lighting } & \multicolumn{2}{c}{ Cases } & \multicolumn{2}{c}{ Non-Cases } & \multicolumn{2}{c}{ Total } \\
\cline { 2 - 7 } & $\mathbf{n}$ & $\%$ & $\mathbf{n}$ & $\%$ & $\mathbf{n}$ & $\%$ \\
\hline Good & 10 & 31.25 & 25 & 78.12 & 35 & 54.69 \\
Not-Good & 22 & 68.75 & 7 & 21.88 & 29 & 45.31 \\
Total & $\mathbf{3 2}$ & $\mathbf{1 0 0}$ & $\mathbf{3 2}$ & $\mathbf{1 0 0}$ & $\mathbf{6 4}$ & $\mathbf{1 0 0}$ \\
\hline
\end{tabular}

The result of Chi square test showed there is a correlation between the conditions of floor with respiratory syndrome cases by $P$ value is $0.001<\alpha(0.05)$. The conditions of houses in the field are the window is still narrow and was not often openedn on the day, not have ventilations, and almost of houses toward north and west. The sun light is necessary because can kill pathogen microorganism in the houses and also decrease the humidity.

f. The Conditions of Houses Temperatures of Respiratory Syndrome Cases in Aribaya Village in 2012

The result of temperatures measurements showed that all of the sample houses are fullfil requirements of health houses $\left(18-30^{\circ} \mathrm{C}\right)$. It opposites to Fatimah (2008), reveals that if the temperatures of the house is not in good quality have risk factors amount 2.674 times higher than others to get respiratory syndrome. ${ }^{10}$ 
g. The Conditions of Houses Humidity of Respiratory Syndrome Cases in Aribaya Village in 2012

The result of the humidity measurements showed that still not included to requirements of health houses, neither control or cases samples. Suryanto (2003) explain that a good humidity is $40-70 \%$ and bad if less than $40 \%$ or more than $70 \%{ }^{11}$ The humidity is closed correlation with condtions of ventilations because a bad air sirculations will affect the temperatures of the house and increasing the humidity. A house with high humidity makes living of rats, cockroach, fungi and makes pathogen microorganisms easly to reproductions, and all of them can will infect the respiratory systems.

h. The Conditions of Mother Knowledge of Respiratory Syndrome Cases in Aribaya Village in 2012

The result of this research showed that the higher cases of respiratory syndrome (1-4 years old = 18 cases) is still in less of knowledges and only 1 cases that have high of knowledge. Mother knowledge is all about hygiene and sanitations of the baby, all about knowing something after seen something, happening something or have teaching something to doing preventions of respiratory syndrome to her babies. ${ }^{9}$

i. The Conditions of Family Member Smooker of Respiratory Syndrome Cases in Aribaya Village in 2012

The result of this research showed that almost of cases samples (31 cases) have family member smookers and only 1 cases that do not have it. The result of Chi square test show there is not-correlation between the family member smookers with respiratory syndrome cases by $P$ value is $0.355>\alpha(0.05)$. Kusnoputranto (1995) explained that smoke from parents or ather family members smoker can increasing risk factors of baby or toddlers to get respiratory syndrome. It depend to how long the baby/toddlers. ${ }^{12}$

j. The Correlations of Level Education to Respiratory Syndrome Cases in Aribaya Village in 2012

The study revealed that almost of samples are Elementary Graduates they are 42 cases $(66 \%)$ and 1 of the case sample is $1^{\text {st }}$ Diploma Graduate. The result of Chi square test show there is not-correlation between level education with respiratory syndrome cases by $P$ value is $0.134>\alpha(0.05)$. It is not according to research of Widyastuti (2005), explained that educations is necessary thing that will be affect someone. ${ }^{13}$ A person who have high education will choose preventive concepts of sick. The low of level education makes difficulty of a person to received information or knowledge about personal hygiene and sanitation.

k. The Correlations of Occupations to Respiratory Syndrome Cases in Aribaya Village in 2012

The result of this research showed that almost of samples are farmer (27 person/84.37\%) and the others are entrepreuner (1 person) and seller (1 person). The result of Chi square test show there is not-correlation between occupations with respiratory syndrome cases by $P$ value is $0.248>\alpha(0.05)$. Widyastuti (2005) explained that the occupations status of a person will describes salary, social status, economics status, education, traumatical risk and health risk in a populations. ${ }^{13}$ The kind of occupation is not a risk factor to get respiratory syndrome in this research. 


\section{Conclusion}

This research study concluded that environmental conditions of the houses is the risk factor correlated respiratory syndrome. They are the conditions of ventilation, kind of floor, temperatures and humidity. Other risk factor is the mother knowledge. It needs closed conseling from Health Center Department and local government to increase the knowledge, awarenes and motivations the Aribaya Village community to makes a health house to prevent the respiratory syndrome.

\section{References}

1. The Ministry of Health of Indonesia Republic, Pemberantasan Penyakit Infeksi Saluran Pernapasan Akut (ISPA), Ditjen P2MPLP, Jakarta, 2001.

2. RISKESDAS, Laporan Nasional 2007, Badan Penelitian dan Pengembangan Kesehatan, Departemen Kesehatan RI, 2007.

3. The Ministry of Health of Indonesia Republic, Pedoman Pemberantasan Penyakit Infeksi Saluran Pernapasan Akut (ISPA) untuk Penanggulangan Pneumonia pada Balita, Ditjen P2MPLP, Jakarta, 2002.

4. Riswandri, Faktor-Faktor yang Berhubungan dengan Kejadian ISPA pada Balita di Desa Warujaya Kecamatan Parung Kabupaten Bogor (Analisis Data Survei Dasar) Bogor, Skripsi, FKM Universitas Indonesia, Jakarta, 2002.

5. Desmon, Hubungan antara Jenis Atap dan Kepadatan Hunian terhadap Penyakit ISPA, www.jurnalkesehatanispa.com, 2002.

6. Abdullah, Pengaruh pemberian ASI terhadap kasus ISPA pada bayi umur 0-4 bulan, Fakultas Kesehaatan Masyarakat Universitas Indonesia, Jakarta, 2003.

7. Riza Yulita, Faktor-faktor yang Berhubungan dengan Kejadian ISPA pada Balita di Kabupaten Bekasi Tahun 2003, Skripsi, Fakultas Kesehatan Masyarakat. Universitas Indonesia, Depok, 2005.

8. Murti Bhisma, Desain dan Ukuran Sampel Untuk Penelitian Kuantitatif dan Kualitatif di Bidang Kesehatan, Jogjakarta: Gadjah Mada University Press, 2006.

9. Ayu CP., Faktor Risiko Kejadian Penyakit ISPA Ringan pada Balita di Kelurahan Ranngkapan Jaya Baru Kota Depok Tahun 2008, Skripsi, Jakarta FKM Universitas Indonesia, 2009.

10. Fatimah S., Faktor Kesehatan Lingkungan Rumah yang Berhubungan dengan Kejadian TB Paru di Kabupaten Cilacap, Tesis, Program Pasca Sarjana Universitas Diponegoro Semarang, 2008.

11. Suryanto, Hubungan Sanitasi Rumah dan Faktor Intern Anak Balita dengan Kejadian ISPA pada Anak Balita, Skripsi, FKM Universitas Airlangga, 2003.

12. Kusnoputranto, 1995 dalam Permatasari CAE., Faktor Risiko Kejadian Gejala ISPA Ringan pada Baduta di Rangkapan Jaya Baru Kota Depok Tahun 2008 (Analisis Data Sekunder Tahun 2008), Skripsi, FKM Universitas Indonesia, 2009.

13. Widyastuti, 2005 dalam Teher L., Gambaran beberapa Faktor Penyebab Diare pada Pasien di Ruangan Perawatan Interna RSUD Toto Kabila Kab. Bone Bolango, Thesis, Universitas Negeri Gorontalo, 2014. 